\title{
TALVEZ SEJA MENTIRA: ESTUDOS SOBRE NARRATIVAS FOTOGRÁFICAS FICCIONAIS NA ARTE CONTEMPORÂNEA
}

\author{
MAYBE IT'S A LIE: STUDIES ABOUT FICTIONAL \\ PHOTOGRAPHIC NARRATIVES IN CONTEMPORARY ART \\ TAL VEZ SEA MENTIRA: ESTUDIOS SOBRE \\ LA FOTO NARRATIVAS DE FICCIÓN EN EL ARTE CONTEMPORÁNEO
}

Havane Melo ${ }^{1}$ 


\section{Resumo}

Essa pesquisa visa esclarecer o significado da fotografia cinematográfica contemporânea, localizando-a no espaço-tempo social, baseada nos textos de autores como Charlotte Cotton, Vilém Flusser e outros emprestados de diversas áreas do conhecimento como a comunicação, a literatura e a antropologia, porém, preocupados em tratar da narrativa ficcional e da interpretação simbólica. As ideias são sustentadas principalmente sobre o tripé: ficção, narrativa e interpretação, destacando a construção identitária, a participação do modelo e do público na interpretação de um trabalho e outros recursos característicos da narrativa visual que podem ser utilizados pelo autor como forma de aproximação com o receptor. Ao longo do texto, apontamos algumas obras, sobre as quais tecemos considerações acerca da narrativa e processo de criação, a fim de exemplificar os conceitos discutidos. Como resultado da pesquisa, inserimos alguns trabalhos autorais, desenvolvidos sob o manto dos conceitos discutidos.

Palavras-chave: Fotografia. Narrativa. Ficção.
The following research aims to clarify the meaning of contemporary cinematographic photography, locating it in social space-time, based on the texts of authors as Charlotte Cotton and Vilém Flusser, among others from several areas of knowledge such as communication, literature and anthropology, however, concerned with dealing with fictional narrative and symbolic interpretation. The fallowing ideas are holded mainly on the tripod: fiction, narrative and interpretation, emphasizing the construction of identity, the participation of the model and the public in the interpretation of a work and other features characteristic of the visual narrative that can be used by the author as a way of approaching the receiver. Throughout the text, some works were choosen to make considerations about its narrative and creation process, in order to exemplify the concepts discussed. As a result of the research, we have inserted some works of authorship, developed under the mantle of the concepts discussed.

Key-words: Photography. Narrative. Fiction.

\footnotetext{
1 Doutoranda em artes visuais, vinculada ao PPGAV-UnB, bolsista CAPES Mestre em Comunicação pela UnB. Bacharel em direito pela UFPE. Artista visual, fotógrafa e designer gráfico. Essa pesquisa foi desenvolvida com bolsa auxílio fornecida pela CAPES. arte@havanemelo.com

Lattes: http://lattes.cnpq.br/1734265519220937

Orcid: https://orcid.org/0000-0003-1284-1635
} 


\section{Resumen}

Esta investigación tiene como objetivo aclarar el significado de la fotografía ficticia contemporánea, ubicándola en el espacio-tiempo social, basada en los textos de autores como Charlotte Cotton, Vilém Flusser y otros tomados de diversas áreas del conocimiento, como la comunicación, la literatura y la antropología, preocupados por tratar con la narrativa ficticia y la interpretación simbólica. Las ideas se basan principalmente en el trípode: ficción, narrativa e interpretación, destacando la construcción de la identidad, la participación del modelo y el público en la interpretación de una obra y otros rasgos característicos de la narrativa visual que el autor puede utilizar para abordar el receptor. Como resultado de la investigación, señalamos algunas obras desarrolladas bajo el manto de los conceptos discutidos y hacemos consideraciones sobre el proceso narrativo y de creación.

Palabras-clave: Fotografía. Narrativa. Ficción. 


\section{Introdução}

A fotografia encenada (daí o título: talvez seja mentira), que se interessa por exprimir ideias ou sentimentos, é dirigida para provocar as emoções humanas. Existem vários fatores imagéticos que estimulam sensações, como a paleta de cores, a postura e a fisionomia do sujeito retratado, a iluminação, a ambientação, a presença de informações climáticas como névoa, chuva, calor, etc. A criação e a execução de um conceito sólido da encenação fotográfica exigem, além da intenção do autor, o estudo das emoções humanas a serem despertas, a fim de induzir uma catarse ao final da experiência que, no caso da apreciação de uma fotografia, ocorre quando o espectador julga apropriado, posto que não há a indicação de um final, como ocorre no vídeo.

Nas artes plásticas, a catarse pode ocorrer no espectador que contempla uma obra (imagem, som, vídeo ou performance) e essa the desperta emoções. Ao contemplar uma encenação, obra de arte ou composição musical, o espectador pode sentir-se conectado com as ideias emanadas da apresentação e, ao final, sentir-se purificado, punido ou aliviado. São essas conclusões emocionais, advindas da representação de uma tragédia, a que chamamos catarse, em sintonia com os pensamentos de Aristóteles (2004, p. 43).

O conjunto estético e artístico composto pela organização de elementos fotográficos em cena e/ou a sua posterior organização expositiva formam uma narrativa visual que, se criada no ambiente do imaginário e da invenção - e não apenas para registro -, nos permite adentrar os campos da ficção. Contudo, para funcionar, a narrativa ficcional depende da aceitação do espectador e, para atingir tal finalidade, pode utilizar de recursos narrativos e simbólicos que facilitem a aproximação identitária e estimulem os processos imaginativos. Dentro de nosso estudo fotográfico, nos direcionamos para a fotografia de invenção, um estilo autêntico e distinto das fotografias documentário, jornalística, etnográfica ou qualquer outra vertente que tenha a intenção de retratar cenas e sujeitos restritos à realidade.

Portanto, o objetivo principal dessa pesquisa é o estudo das possibilidades de narrativas fotográficas ficcionais através da explanação de conceitos e artistas contemporâneos. Para tanto, vamos nos apoiar em três pontos principais: o desenvolvimento do conceito de fotografia de quadros-vivos e suas possibilidades (ficção como linguagem fotográfica); a construção de uma história (narrativa como parte indispensável da completude de uma obra fotográfica); a relevância do imaginário simbólico para a construção de significados (interpretação da atuação: aquilo que se julga verdadeiro). Eventualmente, serão realizadas considerações acerca do receptor da imagem e sobre o processo de funcionamento dessa recepção na arte, discutindo recursos que podem ser utilizados pelo artista para alcançar o espectador. Ao longo do texto, discorreremos um pouco sobre como alguns artistas contemporâneos desenvolveram esses elementos em seus trabalhos fotográficos.

Para a escolha do método utilizado, foram seguidos os ensinamentos de Silvio Zamboni (2006, p. 67), para quem a metodologia em artes não é tão linear quanto na ciência, e diferentes etapas da pesquisa mesclam-se até chegarmos a um resultado 
final. Para o autor, a apresentação dos resultados faz parte da própria obra de arte realizada. Sendo assim, para cada etapa desse trabalho estamos produzindo composições fotográficas em sintonia com os conceitos aqui destacados e utilizando como referência os artistas citados. Em alguns momentos, usarei como referência também trabalhos de minha autoria, a fim de ilustrar os resultados obtidos até aqui. Por se tratar de uma pesquisa em andamento, parte integrante do meu doutoramento em artes visuais na área de poéticas contemporâneas com ênfase em fotografia, saliento que os resultados ainda não estão completos. Limitei-me, portanto, a mencionar apenas alguns trabalhos autorais que enfatizam os principais argumentos destacados ao longo do texto, deixando de fora outros materiais visuais em prol do espaço para a escrita.

Diante do exposto, convido o leitor a adentrar o universo da narrativa fotográfica ficcional, tendência que surgiu por volta da década de 1960. Com a consolidação dos meios de captura fotográfica como parte da linguagem social contemporânea, hoje toma de assalto áreas tidas como tradicionais na fotografia, a exemplo do jornalismo e do documentário, dedicadas inicialmente ao registro da realidade concreta e cujas fronteiras de atuação podem beirar a ficção, conforme demonstraremos adiante.

\section{Ficção como linguagem fotográfica}

Para Michel Maffesoli, "a ficção é uma necessidade cotidiana. Cada um, para existir, conta-se uma história" (2010, p. 266). Assim, mesclamos, cotidianamente, realidade com invenção como parte de nossa existência intelectual, a fim de manifestar sentidos e justificar acontecimentos. No processo de produção artística calcado sobre os pilares da ficção, o autor deve estar ciente de que a interpretação de suas ideias estará vinculada às experiências e emoções do espectador.

Esse estilo de fotografia- cuja leitura carece de interpretação e depende do espectador, suas vivências e conteúdos psicológicos - é descrita como fotografia de quadros ou de quadros-vivos, como nos explica Charlotte Cotton, no capítulo intitulado Era uma vez do seu livro A fotografia como arte contemporânea (2010, p. 49-79). Essa narrativa surgiu em meados do século XX, principalmente com o trabalho do artista Duane Michals (1932), que se preocupava em abordar questões metafísicas e explorar narrativas psicológicas em vez de documentar a realidade externa. No final da década de 1960, Michals começou a trabalhar com suas primeiras imagens narrativas sequenciais (HACKING, 2012, p. 340). Por volta de 1966, Michals começou a abordar narrativas que desconstroem o lógico e confortável em prol de histórias nas quais predominam o devaneio e que servem de expressão para seus anseios pessoais, subjetivos. Suas obras, compostas por sequências fotográficas que contam uma pequena história ou situação, trazem personagens criativamente trabalhados, com indicativos de passagens de tempo, evolução e outros simbolismos que compõem o imaginário do leitor. Michals, reconhecido como um dos precursores da fotografia construída (VASQUES, 2014, p. 211), com frequência optava por uma narrativa direta, preocupando-se em criar imagens a partir de sua própria imaginação e referências. Vejamos: 

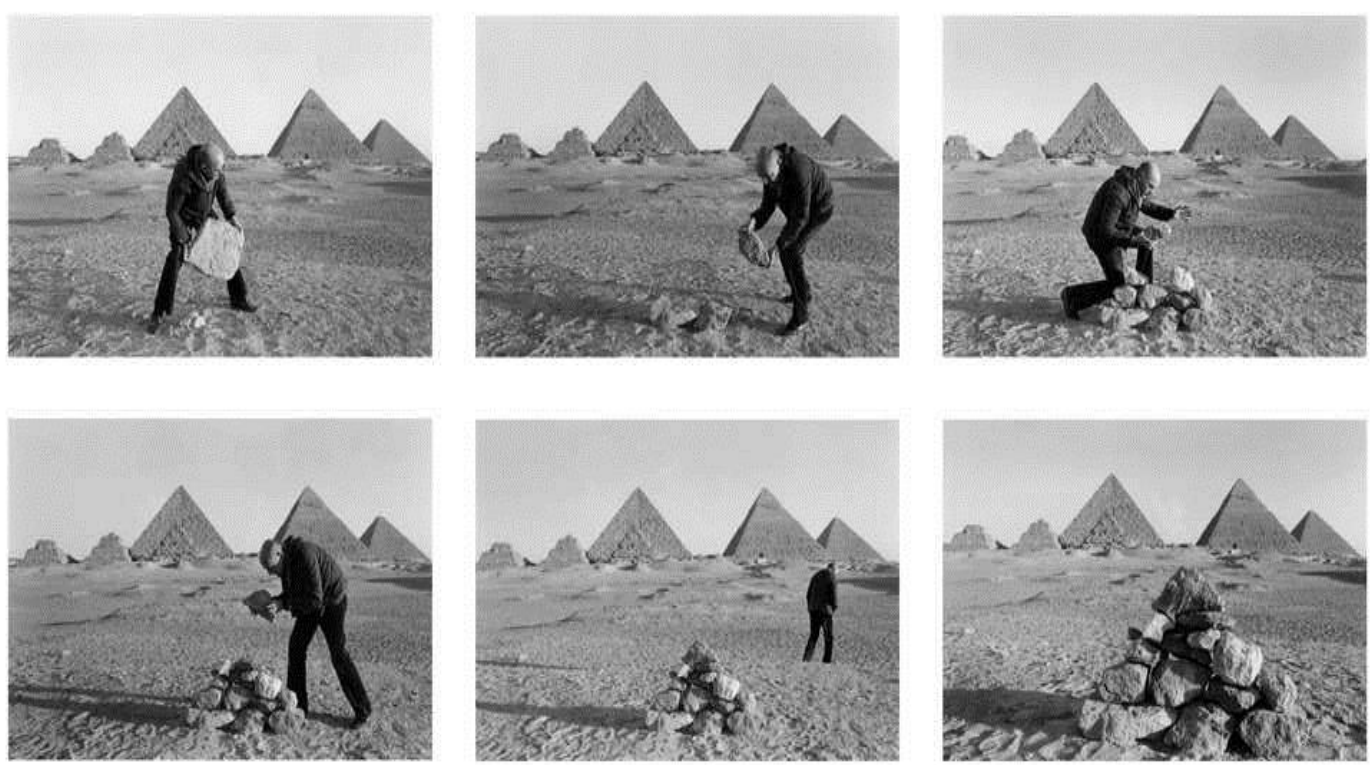

MICHELS, D. I build a Pyramid, 1978.

Foi nesse período, principalmente entre as décadas de 1960 e 1970, que ocorreu a explosão das produções que firmaram o estilo, influenciadas pela estética da publicidade, pela popularização da câmera fotográfica como utensílio doméstico para registro e pela pop art. A visão de artistas com grande apelo publicitário ou que atuavam nessa área e dominavam sua linguagem, como Bárbara Kruger e Andy Warhol, foram importantes para redirecionar os rumos da prática da fotografia como linguagem artística. Da mesma forma, também a difusão do termo "arte conceitual", cunhado por Sol LeWitt em 1967, foi fundamental nesse redirecionamento. Entre outros adeptos contemporâneos do estilo, podemos citar os artistas Jeff Wall, Sharon Lockhart, Philip-Lorca diCorcia e Ryan McGinley.

Fotografias de quadros-vivos são compostas por cenas coreografadas para o espectador, utilizando a montagem cênica de um evento ou enfatizando a natureza artificial da fotografia, a fim de ressaltar seu caráter imaginativo ou ficcional. Nesse contexto, o fotógrafo pode trabalhar tanto sozinho, como um pintor, ou orquestrando um grupo (formado por modelos, assistentes, iluminação, entre outros), atuando como um diretor de arte ou de cinema. Por conseguinte, a iluminação típica desse tipo de fotografia é conhecida como cinematográfica, posto que dramatiza e naturaliza a cena criada, contrastando com a fotografia comercial ou de estúdio, cuja iluminação tende a ser uniforme e artificial (COTTON, 2010).

Assim, a característica basilar das fotografias de quadros-vivos é a encenação, com grande carga de dramaticidade, muitas vezes ambígua, cujo significado o observador deve completar com sua própria interpretação. Não se exige a verdade de conteúdo, tal como ocorre na fotografia documental ou de registro, mas, sim, uma interpretação dos seus significados possíveis. No entanto, a fim de induzir certos entendimentos e alcançar a catarse, diversos recursos podem ser utilizados, como, por exemplo, ocultar o rosto do personagem para evocar sentimentos de ansiedade ou incerteza ou, ainda, congelar parte de um movimento realizado dando margem para 
ambiguidades na mente do leitor. A principal característica desse tipo de fotografia é, justamente, a transmissão indireta de informações, com significados abertos. O leitor é intérprete e não existem verdades absolutas na fotografia de quadros-vivos (COTTON, 2010).

Outro aspecto da problemática ficcional, discorrido na pesquisa da professora Susana Dobal (2013, p.77), é que a encenação tem se tornado recorrente inclusive dentro dos domínios da fotografia documental. Para ela, a fotografia contemporânea aponta para o retorno da ficção através do duplo movimento de desvendar o caráter fictício da construção do real e de explicitamente simular a realidade. A pesquisa de Dobal, assim como o livro de Cotton, indicam a fotografia ficcional como tendência contemporânea e, portanto, reflexo do nosso contexto histórico, da nossa cultura. Se antes a fotografia era exaltada como representação fiel da realidade, hoje a ficção predomina, mesmo que praticada de forma inconsciente pelo sujeito que captura a imagem.

Em outro capítulo do mesmo livro, Alguma coisa e nada, Cotton (2010, p.115135) discorre sobre uma sequência de fotografias complexas de objetos banais, do cotidiano, sobre os quais é jogada uma nova carga visual, rica em possibilidades imaginárias, retirando-os do lugar-comum para gerar novas possibilidades interpretativas. Tais fotos são capazes de induzir o observador a novas reflexões, antes inimagináveis perante os objetos em seu estado trivial. Os resultados alcançados por essas imagens insólitas são obtidos através de técnicas fotográficas (aplicadas ou destruídas) e composições poéticas que visam gerar novas possibilidades para temas comuns, desvinculando-os dos conceitos tradicionais.

Para dar um exemplo da exploração da desconstrução imagética como poética, citamos o trabalho do fotógrafo alemão Wolfgang Tillmans (Abstract Pictures, Collector's Edition, 2011) ${ }^{1}$ e sua abstração de cores e texturas provocadas por acidentes propositais de revelação. Utilizando como recurso estético a danificação do negativo através da revelação artesanal e tendo em mente as desconstruções imagéticas propostas por Tillmans durante o processo de revelação, em 2017 fiz o conjunto de fotos Finjo que não te conheço, cuja principal característica são os blocos de cores sobrepostas formados pelos grãos excessivamente aparentes de filme Mirage Color, Iso 100, vencido em 2008 e clicado com uma câmera analógica Canon EOS 3000 . 

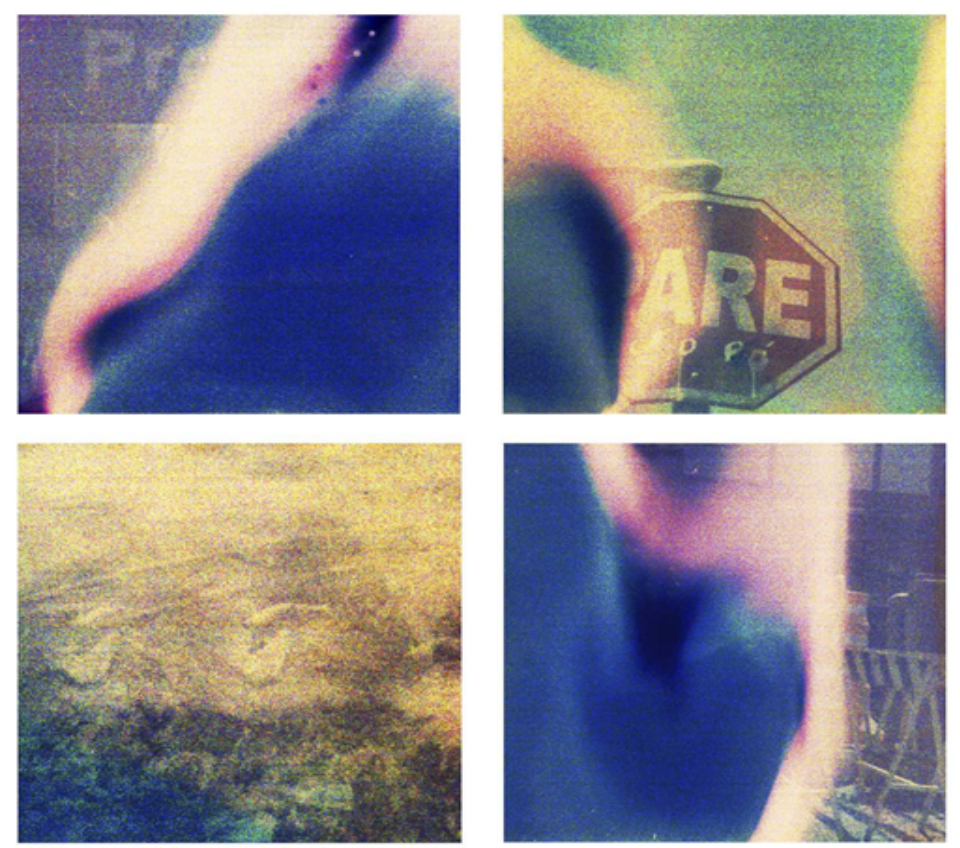

MELO, H. Finjo que não te conheço, 2017.

O objetivo dessa sequência é - além de desprezar os direcionamentos técnicos que visam a excelência induzida pela máquina que doutrina o olhar humano a padrões de beleza limitados - ironizar as formas de reconhecimento, assumindo que as está negando, desta forma, sendo um movimento deliberado posto a cabo pelo sujeito que fala. Essa ideia básica, cerne da criação da obra, está implícita desde o título, que inicia (ou conclui, a depender do sentido da leitura) o processo interpretativo. Também é pretensão desse trabalho abrir uma discussão sobre opostos e contraposições, intercalando cores, texturas e localizações opostas, porém, coordenadas (céu verde $\mathrm{x}$ solo amarelo, por exemplo). Como elemento complementar, desponta o texto (uma aparição recorrente na minha poética e raramente em sentido denotativo) também desfigurado, tornando-se ilegível, contribuindo para aumentar o mistério da informação e a abstração do conjunto, ainda que seja possivel inferir a leitura das palavras "pare" e "pó", gerando uma compreensão secundária e interna da obra. Espera-se, portanto, que seja um trabalho de plataforma conceitual, lido em camadas, desde o título, e que provoque mais sensações e desconfortos que certezas, rompendo com um estilo clássico de narrativa e de fotografar.

\section{Narrativa como parte indispensável da completude de uma obra fotográfica}

A partir do momento em que reunimos um grupo de imagens com pretensões de demonstrar algo, seja ideia, informação, conceito ou sensação, estamos diante de uma narrativa visual. Nas artes, a fotografia nem sempre está contando uma história nos seus moldes tradicionais ou reais. Nesse caso, o desafio do autor é tornar-se, de alguma forma, inteligível para os diferentes tipos de leitores, de modo a afetá-los de alguma forma. A fim de explicar o fenômeno de leitura e participação do espectador sobre a obra, Jacques Rancière, em seu livro $O$ espectador emancipado, nos fala: 


\begin{abstract}
Ele [o espectador] observa, seleciona, compara, interpreta. Relaciona o que vê com muitas outras coisas que viu em outras cenas, em outros tipos de lugares. Compõe seu próprio poema com os elementos do poema que tem diante de si. Participa da performance refazendo-a à sua maneira, furtando-se, por exemplo, à energia vital que esta supostamente deve transmitir para transformá-la em pura imagem e associar essa pura imagem a uma história que leu ou sonhou, viveu ou inventou. Assim, são, ao mesmo tempo, espectadores distantes e intérpretes ativos do espetáculo que lhes é proposto (2014, p. 17).
\end{abstract}

Ideia semelhante foi esboçada por Doc Comparato em seu Da criação ao roteiro, no qual destrincha as regras de funcionamento da indústria audiovisual. Nesse livro, Comparato explica a consciência, o senso crítico e expectativa do receptor para emocionar-se e frustrar-se quando se propõe a assistir um espetáculo (2009, p. 363). Sabemos, destarte, que a partir do momento em que uma obra vai para o mundo, o autor perde o controle sobre suas intenções originais em prol das experiências individuais experimentadas pelo espectador. Para facilitar a conexão entre as intenções do autor e os receptores, é importante que o artista conheça o poder narrativo de alguns recursos. Talvez o exemplo mais claro que podemos citar aqui, por ser um recurso bem utilizado pela publicidade, seja a influência da teoria das cores no significado e no despertar de emoções. Outro exemplo, também muito comum, são as posturas típicas que o corpo humano assume para demonstrar suas intenções (comunicação indireta). Todavia, exemplos mais complexos podem ser abordados, como as reflexões de Rancière (2014, p.83-125) sobre imagem intolerável e imagem pensativa.

Resumindo tais conceitos, podemos entender a imagem intolerável como aquela que não se deseja ver, de caráter grotesco e incômodo ou que traga cenas reais de massacre, miséria, violência ou qualquer outro conceito social tido como inconveniente ou desconfortável. Contudo, esse tipo de fotografia é a linguagem escolhida por diversos artistas, como Sebastião Salgado e Roger Ballen, embora desenvolvam poéticas distintas. Seus trabalhos - aqui meramente pontuados, uma vez que se tratam de conjuntos imagéticos que discutem percepções mais profundas costumam ser compostos em séries, formando agrupamentos de imagem que nos contam histórias reais ou sombrias, respectivamente, sob o ponto de vista de cada autor. Salgado aproxima-se do documentário baseado na realidade, embora retrate elementos e pessoas sob sua visão poética e apuro técnico. Ballen, por sua vez, mantém seu trabalho mais próximo da ficção, do onírico, da subjetividade e da mistura de elementos que compõem sua estética vagueando pelo grotesco e aterrador. Vejamos: 


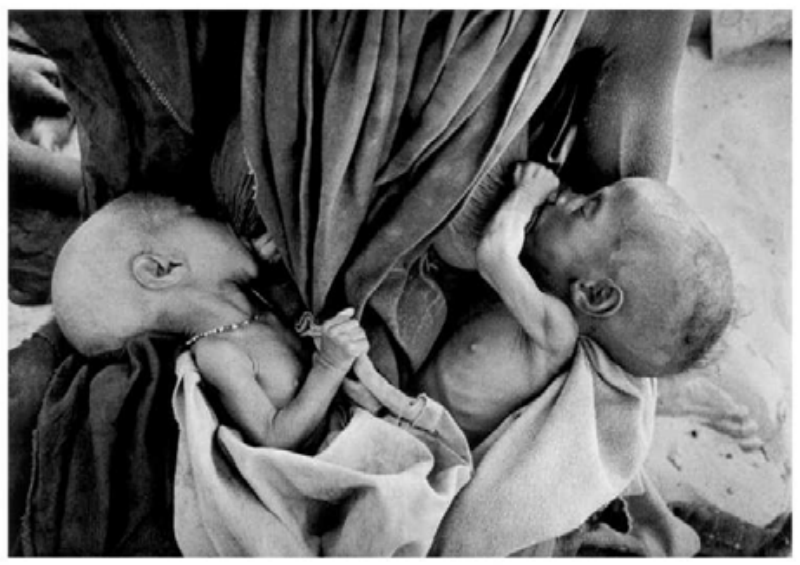

SALGADO, S. Êxodos, 2000.

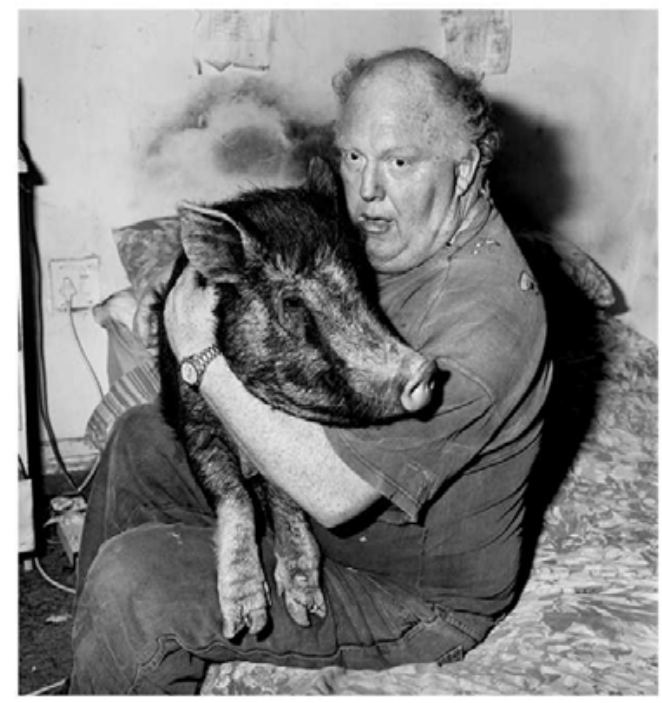

BALLEN, R. Brian with pet pig, 1998.

A segunda questão levantada por Rancière, a da imagem pensativa, trata da pensatividade imagética, da presença latente de um regime de expressão em outro (2014, p. 118). É exatamente o que também percebemos na segunda imagem acima, de Ballen. O rosto de Brian transmite diversas informações ao mesmo tempo em que evoca contemplatividade por parte do sujeito protagonista da cena. Esse flagrante do seu pensamento, aliado a uma detalhada escolha de elementos inconvencionais para a composição (pois, no atual contexto histórico-social, abraçar um porco não é ato comum e dar o protagonismo para um homem cuja imagem sugere distúrbios mentais não é convencional, assim como também não é comum a presença de ambos em ambiente cujo desconforto é acentuado pela invasão de elementos secundários ao lado esquerdo da cena), é o que leva o espectador aos confins das narrativas forjadas por Ballen.

Ainda, para sustentar a atenção do observador, pode o autor fazer uso de outros recursos narrativos e figuras de linguagem como analogias, metáforas, ironias e metonímias visuais. Esses recursos servem como estratégias de atração que estimulam a cognição do espectador. Desse modo, o sujeito desenvolve uma consciência narrativa pessoal e a conecta à questão identitária.

A artista americana pós-moderna Cindy Sherman pode ser considerada mestra na criação de personagens identitários utilizando a si própria como modelo e fotógrafa, simultaneamente. A interpretação de uma vasta variedade de estereótipos e poses femininas clichês, apropriadamente questionados em vista das convenções sociais ainda vigentes na década de 1970, conferiu à artista o papel político de crítica da cultura de massa e da construção da feminilidade socialmente imposta. Em toda sua icônica série Fotograma sem título (1978-1979), composta por 69 fotografias em preto e branco, a artista está estrategicamente caracterizada com diferentes tipos femininos facilmente identificáveis como, por exemplo, uma atriz de cinema em Fotograma sem título n. 13, declaradamente inspirado em Brigitte Bardot. Mais que uma conexão identitária, a intenção de Sherman ao apresentar-se como esses estereótipos femininos sugere uma reflexão acerca dos códigos culturais que regem 
a construção da feminilidade, aprofundando a questão da identificação (ou rejeição, no caso) do espectador com a arte (HACKING, 2012, p. 423).

A construção da identidade é um problema que afeta diretamente o construtor de narrativas, pois a falta de um elemento de identificação torna mais difícil o desafio de afetar o espectador. É preciso centrar em alguma informação para a construção de um sentido. Isto pode se dar por meio de qualquer aspecto do trabalho, desde que desenvolvido de forma consciente: a paleta de cores, o desfoque, a geometria, as pessoas, a iluminação, os objetos, etc.

A questão da consciência narrativa pessoal está intimamente ligada à construção identitária. Esse fenômeno é complexo, pois depende, a princípio, de três esferas: a autoexibição consciente do sujeito, a recepção deste pelos demais personagens sociais e o domínio dos códigos de comunicação vigentes naquela conjuntura (COMPARATO, 2009). Criada uma identidade, a personagem deve ser inserida em um contexto. Mesmo no retrato em estúdio procura-se dar sentido ao corpo ou neutralizá-lo (como ocorre com frequência na fotografia de moda e na publicitária), para que haja um significado percorrendo a composição. Tomemos, como exemplo, a série da fotógrafa holandesa Rineke Dijkstra retratando toureiros, em 1994. Tais retratos, limpos em cenários, iluminação e composição trazem apenas o toureiro após o momento de ação, sujo de sangue e com as vestimentas (características de sua atividade, logo, identitárias) rasgadas. A repetição de elementos mantém a unidade entre os retratos, mas preserva a noção de individualidade de cada toureiro retratado. Dijkstra utiliza o mesmo recurso da repetição em outras séries de retratos, ao mesmo tempo em que mantém um elemento em comum ligando seus modelos, trazendo à tona elementos da individualidade, como expressões faciais e corporais.
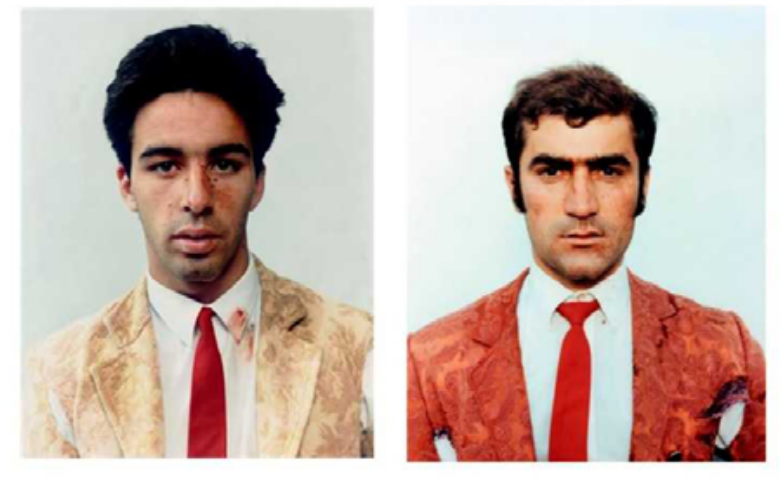

DIJKSTRA, R. Villa Franca di Xira e Montenor. 1994.
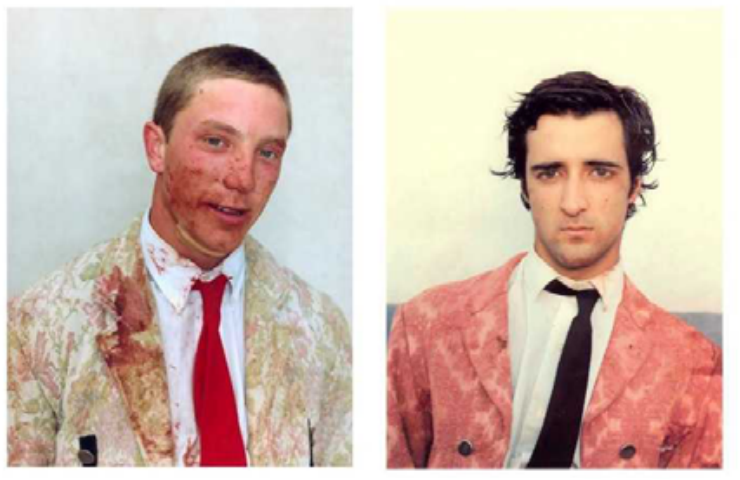

A consequência dessa constatação identitária faz com que a narrativa torne-se mais convincente à medida que se aproxima dos estereótipos, dos mitos, enfim, das representações culturais consagradas e do processo de identificação que preside toda e qualquer agregação social (MAFFESOLI, 2010, p. 286). Essa forma de suporte ao individualismo, Maffesoli chama de "lógica da identificação" (2010, p. 286), responsável por auxiliar no suporte da cola social de um grupo.

Outro elemento que contribui para a fixação social é o inconsciente coletivo, ou seja, a parte mais profunda da psique humana onde estão ancoradas as imagens ancestrais comuns a todos os seres humanos e que auxiliam no processo de identi- 
ficação. O inconsciente coletivo costuma atuar em conjunto com a imaginação, definida como a capacidade de raciocinar por meio de imagens através do uso da memória (COMPARATO, 2009, p. 486).

Ao criar uma imagem, estamos realizando a representação de algo. A imaginação é a grande aliada nesse processo, pois é a "capacidade de codificar fenômenos de quatro dimensões em símbolos planos e decodificar as mensagens assim codificadas" (FLUSSER, 1998, p. 27). As informações que o autor fornece dependem, em parte, da imaginação do receptor para serem aceitas como leitura da problemática levantada pela obra fotográfica. Do mesmo modo, o autor se faz valer do caráter conotativo dos símbolos para alcançar o espaço interpretativo do espectador. Assim como ocorre o acordo tácito de aceitação entre escritor e leitor na literatura de ficção e fantasia, o mesmo acordo está firmado entre o artista que utiliza como linguagem a fotografia ficcional e seu espectador. Para Flusser (2008, p. 24), é certo que:

(...) os produtores de imagens sabem perfeitamente que toda visão é subjetiva e privada, e que suas imagens diferem das precedentes, mas assumem que tal subjetividade é privada, e ela própria, resultado do código de mitos, o qual, por sua vez, assume imutável e eterno.

\section{Interpretação da atuação: aquilo que se julga verdadeiro}

Em cenas controladas, frequentemente, a ação do modelo surge como uma reação espontânea à cena orquestrada pelo fotógrafo. Esse controle provoca expectativas relacionadas à interpretação do modelo e do espectador. Uma boa construção de cena, capaz de induzir essa interpretação e levar o espectador à catarse, é fruto de pesquisas e/ou experimentalismos do fotógrafo. A eficiência do resultado alcançado cresce junto com o desenvolvimento de um estilo autoral de fotografia, definido pela temática, técnica, experiência, equipamentos e suportes escolhidos pelo artista para apresentar sua obra.

Medos, fantasias, subjetividades, delírios, inseguranças, alucinações e ambiguidades são alcançados pela elaboração consciente de cenas. A postura assumida pelo modelo também interfere no significado, tal qual ocorre com o artista durante a performance. Não obstante, sabemos que a performance é uma outra linguagem detentora de códigos próprios e, se aparece aqui de forma casual, é para ilustrar a diversificação das possibilidades de atuação.

Como diz Tania Rivera (2013, p. 31), além da presença do corpo, a performance incita a passagem do tempo, enfatizando o caráter temporal da ação. Essa característica é o principal diferencial entre as duas linguagens, já que a fotografia é objeto estático. Ademais, a não ser que o modelo seja o próprio autor da obra, sua autonomia também pode ser questionada na fotografia artística ficcional, pois esse local de fala pertence ao artista, ao criador da obra e não ao modelo.

Na performance, o sujeito é lido como acontecimento. Na fotografia narrativa, ele é lido como personagem, pois há uma história e provavelmente uma conexão de fatos, gestos ou pessoas. Observe essa foto do artista Jeff Wall: 


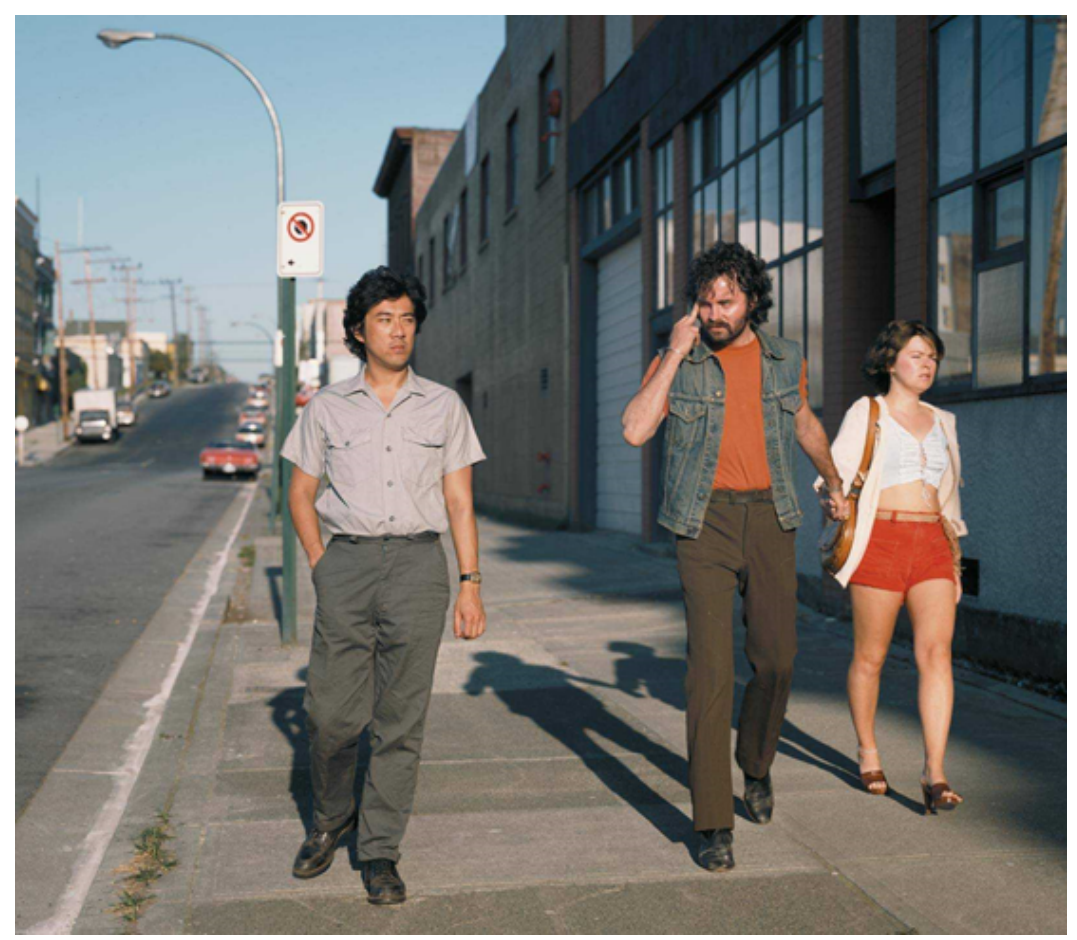

WALL, J. Mimic. 1982.

A narrativa é uma latente no trabalho de Wall, seus trabalhos muitas vezes são imagens congeladas de ações, capturando momentos fugazes e em estilo documentário, característico da fotografia de rua. A foto acima, especificamente, é a reconstrução de uma cena verídica presenciada por Wall. Esse tipo de ideia, baseada na memória ou vivência pessoal, Comparato vai chamar de ideia selecionada. Para o autor, aquilo de mais íntimo, retirado do fundo de nós mesmos, frequentemente, é o mais universal (2009, p. 46).

Por se tratar de uma construção de cena, Wall ${ }^{2}$ utiliza o termo fotografias cinematográficas para se referir ao próprio trabalho. A chave para compreender a obra está na leitura social e política do gesto praticado pelo personagem central. Sua compreensão também conta com a composição da cena, a organização dos personagens (como a mulher em recuo e o homem de cinza em primeiro plano) e a postura corporal de todos: firmeza, agressão, alienação, respectivamente. Cada um está em seu devido lugar, repassando para o observador suas informações específicas, numa caracterização particular dos personagens e seus elementos. Embora, claro, essas informações possam adquirir diferentes significados de acordo com as experiências de cada leitor. Umberto Eco já falou sobre o tema em seu Seis passeios pelos bosques da ficção (1994) e acrescentou:

(...) Ao lermos uma narrativa, fugimos da ansiedade que nos assalta quando tentamos dizer algo de verdadeiro a respeito do mundo.

Essa é a função consoladora da narrativa - a razão pela qual as pessoas contam histórias e têm contado histórias desde o início dos tempos. E sempre foi a função suprema do mito: encontrar uma forma no tumulto da experiência humana (ECO, 1994, p.93). 
A narrativa, portanto, contém o gancho que liga o observador à fotografia cinematográfica que, como tal, vem atrelada a outros elementos de caráter cênico, como objetos, iluminação, figurino, etc. É de suma importância para o desenvolvimento do assunto fotográfico nesse estilo. O modelo infantil, o jovem, o idoso, o homem, a mulher ou mesmo a ausência de corpos humanos na imagem induzem interpretações e enfatizam determinados aspectos da existência humana, permitindo entrever posturas ou insinuações do artista/autor.

Os estereótipos também contribuem para a criação de alegorias. E a mistificação tragicômica, conforme expôs Cotton (2010, p. 30), contribui para a criação de uma persona artística, seja no âmbito pictórico, fotográfico ou literário. Tal ideia está profundamente relacionada com as noções de Maffesoli (2001) de que o real é acionado pela eficácia do imaginário e das construções do espírito.

Assim, nos resta discutir as questões dos símbolos que habitam nosso imaginário. Baseado na definição clássica de símbolo oferecida por Creuzer, Jung, Lalande e outros, Gilbert Durand nos explica que três características delimitam a compreensão desta noção:

Em primeiro lugar, o aspecto concreto (sensível, imagético, figurado, etc.) do significante, em seguida a sua característica ótima: é o melhor para evocar (fazer conhecer, sugerir, epifanizar, etc.) o significado, e, por último, "o fato de que este é impossível de aprender" (ver, imaginar, compreender, etc.) direta ou indiretamente. Dito de outro modo, o símbolo é um sistema de conhecimento indireto em que o significado e o significante mais ou menos anulam a "ruptura", um pouco à maneira de Jacques Derrida que se insurge contra a ruptura saussuriana. O símbolo é um caso limite do conhecimento indireto onde, paradoxalmente, este último tende a tornar-se direto - mas num plano diferente do sinal biológico ou do discurso lógico -; o seu imediatismo visa o plano da gnosis como num movimento assintótico. (1996, p. 73)

Disso, aferimos que Durand constrói o símbolo sobre o significante, o significado e o sentido-variável-produzido pela complementação de ambos. Criar fotografia é uma forma de gerar significados. $O$ significante mais o significado formam o signo que é representação do referente, ou seja, de um aspecto da realidade. Desse cenário de ideias, podemos extrair variadas interpretações baseadas no mesmo fato, a depender do aspecto da leitura da fotografia. Para a interpretação da foto cinematográfica, além de personagens, podemos considerar códigos, contextos, textos, ideias, costumes, crenças, ideologias, rituais, etc. Toda prática, em suma, dotada de significado dentro das relações humanas, em qualquer esfera. Desse modo, o mundo real, concreto, torna-se elemento secundário que serve apenas para embasar a ficção narrativa que, de forma oposta, pode funcionar em termos conotativos.

Um exemplo da interpretação baseada em signos encontra-se na instalação fotográfica Krisis, que desenvolvi em 2016, apoiada, entre outros, na noção de tragédia delimitada por Aristóteles em sua obra Poética. A tragédia, para Aristóteles, é a representação de uma ação elevada, de alguma extensão e completa, com atores atuando e que desperta piedade, temor, horror, pena, tendo por resultado a catarse dessas emoções (2004, p. 43 e 48). 

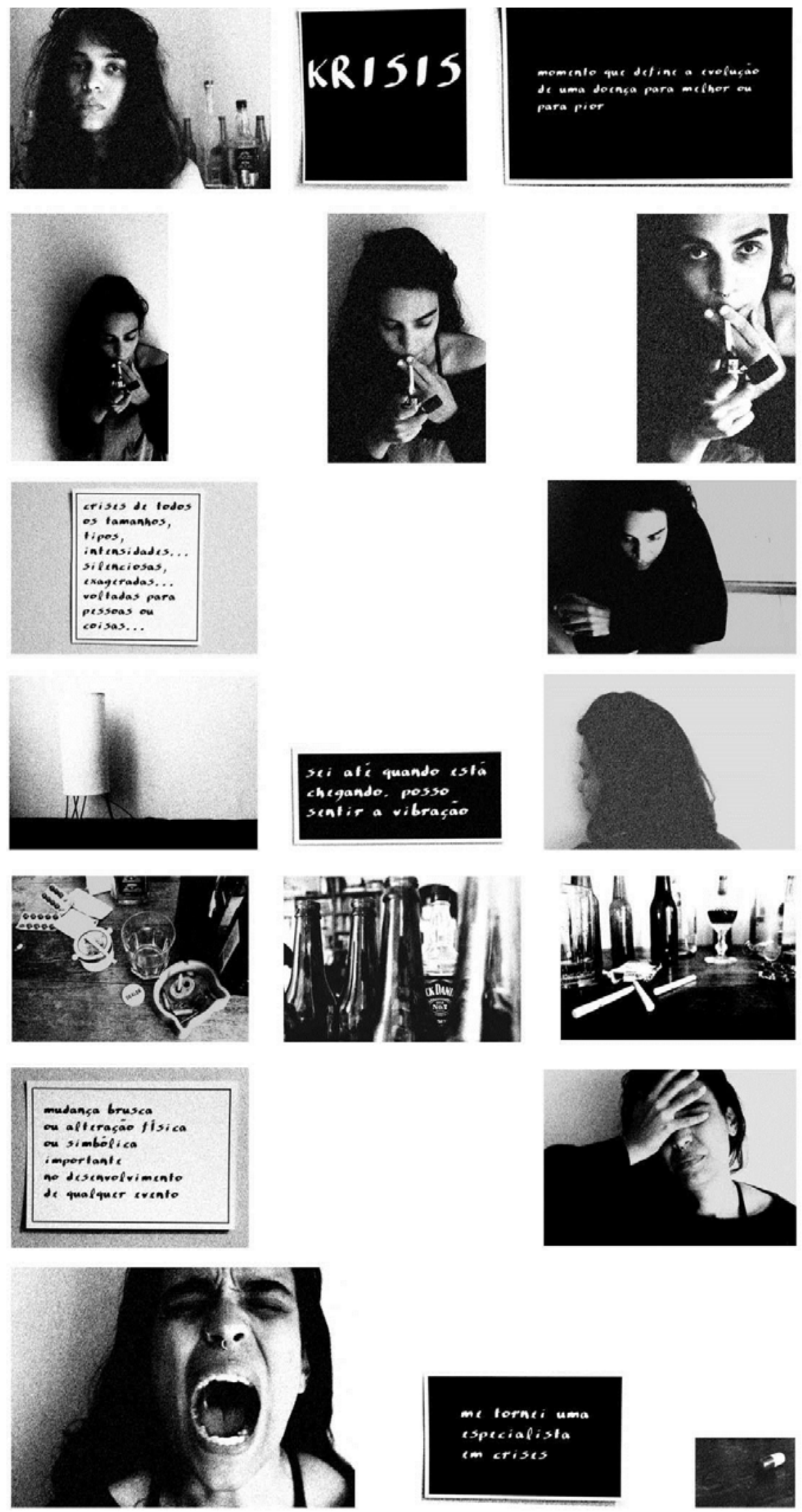

MELO,H. Krisis. 2016. 
Como a narrativa longa que é, se comparada a trabalhos pontuais como Mimic, Krisis demonstra uma caminhada difícil dentro de uma evolução narrativa que vai da solidão ao desespero, sem nunca passar por soluções ou confortos. É o relato de uma personagem feminina em momento de crise - entendida nesse contexto como o indício de uma grande mudança, para melhor ou pior - trilhando um caminho de excessos e estragos para lidar com suas dificuldades. Embora o texto narrativo auxilie consideravelmente na compreensão do trabalho, a ausência de diálogos ou explicações mais detalhadas sobre quem é essa personagem, o que, como, onde e quando se passa a cena, deixa muito conteúdo para ser interpretado subjetiva e diretamente pelo leitor da imagem. Como sujeito dotado de imaginação simbólica comungada socialmente, o observador dessa obra vai utilizar dos elementos, da composição das fotos e dos espaços vazios para compreender as informações que não foram por mim reveladas. Nesse sentido, a sujeira e o ruído das imagens também têm relevância narrativa, pois estimulam a percepção de sentimentos negativos, como dor e sofrimento. E, embora o final possa soar ambíguo para alguns (me tornei uma especialista em crises, diz o último texto), a jornada de dor e sofrimento é inferida pela maioria dos observadores e esse fato advém, principalmente, da comunhão de conteúdo simbólico entre artista e sociedade.

\section{Conclusão}

Como parte de uma pesquisa maior que ainda está em seu início, é precoce assumir essa conclusão como desfecho de um assunto que me é tão caro. No entanto, é preciso pontuar algumas ideias e fechar, mesmo que momentaneamente, os conceitos iniciados páginas atrás.

O lugar da fotografia na arte contemporânea está a salvo, pelo menos por essas datas da contemporaneidade e do pós-modernismo. Depois, outros contextos virão e sobre eles ainda nada podemos afirmar. $O$ fato é que, até aqui, a linguagem fotográfica se mantém tão vigente quanto complexa, inclusive resgatando processos históricos, desenvolvidos há décadas atrás e, desse modo, constantemente abrindo novas possibilidades para si como meio e técnica. Tudo para se reinventar em conjunto com as mudanças sociais frenéticas, típicas do momento social vigente e sua relação com a tecnologia.

Para entender melhor esse contexto da fotografia em consonância com o mundo social, optamos pelo recorte narrativo da ficção, o que, como não poderia deixar de ser, envolve tanto a construção de personagens como a necessidade de que o artista/autor dedique atenção ao seu espectador que, mais do que nunca, é autônomo, consciente e, enfim, emancipado. Iniciamos explorando as possibilidades ficcionais na fotografia, a qual exige a orquestra da cena e dos atores, no que convencionamos chamar aqui de fotografia de quadros-vivos, fotografia inventada ou, ainda, fotografia cinematográfica. O estilo iniciou por volta da década de 1960, com as narrativas subjetivas do artista e fotógrafo autodidata Duane Michals e segue até os dias atuais interferindo, inclusive, na fotografia documental e de registro.

Após a análise de alguns recursos ficcionais, como, por exemplo, a utilização de metáforas, texturas e cores, mergulhamos nas profundezes da narrativa para en- 
tender como funcionam as estruturas de uma história baseada em imagens sequenciais. Para tanto, realizamos várias analogias com as estruturas narrativas tradicionais utilizadas, especialmente, na literatura, e outras tipicamente imagéticas, como a questão identitária e os conceitos de imagens intolerável e pensativa, trabalhados por Jacques Rancière em sua obra $O$ espectador emancipado (2012).

Também discutimos as possibilidades de leituras diversificadas, baseadas na interpretação do observador e atuação do modelo ou artista, de acordo com o caso. Analisamos alguns trabalhos e explanamos a importância do mito e dos estereótipos para comum entendimento social, ao menos quanto às ideias principais de cada trabalho, deixando ainda uma margem de compreensão que será, inevitavelmente, trabalhada de modo único pelo leitor e sua bagagem de experiências. Nesse ponto do problema, ressaltamos a importância de uma construção identitária (Rineke Dijkstra) ou do estranhamento (Sebastião Salgado e Roger Ballen) dentro e fora do retrato, a fim de despertar interesses e afinidades do observador perante a fotografia apresentada.

Buscamos, por fim, apresentar e realizar uma breve leitura e interpretação de alguns trabalhos que utilizam recursos narrativos e ficcionais para lidar com conceitos e abstrações, através da imaginação. Assim, acredito que atingimos nosso objetivo principal que era discorrer sobre as possibilidades de narrativas fotográficas ficcionais através da explanação de conceitos e artista contemporâneos. Ansiamos com esse texto favorecer a produção narrativa visual, baseando-nos em conceitos já sólidos e consagrados da ficção e da arte de contar histórias. Pesquisas como essa, exploradoras de questões narrativas e ficcionais em um meio específico da arte, auxiliam na construção de perspectivas e interpretações sobre a linguagem. Também servem para nos ajudar a localizar artistas contemporâneos, seus precursores e suas produções, considerando conhecimentos de cunho social e localização temporal para compreendermos melhor o contexto no qual as obras são criadas e como tais condições interferem na produção e interpretação do trabalho autoral.

\section{Referências}

ARISTÓTELES. Poética. Coleção Os Pensadores. São Paulo: Nova Cultural, 2004.

ARTNET.COM. Berlin, Nova lorque e Londres. Artworks. Disponível em: <http://www. artnet.com/artists/rineke-dijkstra/3>. Acesso em 21 out. 2018.

BALLEN, R. Transfigurações, fotografias 1968-2012. Curadoria: Daniella Géo. Brasília: Patuá Produções Artísticas, 2017.

BALLEN, R. Johannesburg, South Africa. Disponível em: <https://www.rogerballen. com>. Acesso em 21 out. 2018.

COHEN, R. Performance como linguagem: criação de um tempo-espaço de experimentação. São Paulo: Perspectiva: Editora da Universidade de São Paulo, 1989. 
COMPARATO, D. Da criação ao roteiro: teoria e prática. São Paulo: Summus, 2009.

COTTON, C. A fotografia como arte contemporânea. São Paulo: WMF Martins Fontes, 2010.

Photography is Magic. New York: Aperture, 2015.

DOBAL, S. \& GONÇALVES, O. (Orgs). Fotografia contemporânea: fronteiras e transgressões. Brasília: Casa das Musas, 2013.

DURAND, G. A imaginação simbólica. São Paulo: Cultrix, Editora da Universidade de São Paulo, 1988.

As estruturas antropológicas do imaginário: introdução à arqueologia geral. São Paulo: Martins Fontes, 1997.

. Campos do Imaginário. Lisboa: Ellug, 1996.

ECO, U. Seis passeios pelos bosques da ficção. São Paulo: Companhia das Letras, 1994.

FLUSSER, V. Ensaio sobre a fotografia: para uma filosofia da técnica. Lisboa: Relógio D'Água Editores, 1998.

O universo das imagens técnicas. elogio da superficialidade. São Paulo: Annablume Editora, 2008.

HACKING, J. Tudo sobre fotografia. Rio de Janeiro: Sextante, 2012.

KING, A. Huck Magazine, Londres, Maio, 2016. Disponível em: <http://www.huckmagazine.com/art-and-culture/photography-2/watch-roger-ballens-disturbing-psychological-thriller-theatre-mind/>. Acesso em 21 out. 2018.

KRAUS, R. O fotográfico. Barcelona: Editorial Gustavo Gili, 2002.

MAFFESOLI, M. O imaginário é uma realidade. Revista FAMECOS, Porto Alegre, no 15, p. 74-82, ago. 2001.

No fundo das aparências. Petrópolis, RJ: Vozes, 2010.

MACLENNAN. G. C. El Pais, Fevereiro, 2017. Disponível em: <https://brasil.elpais.com/ brasil/2017/02/16/cultura/1487253964_955625.html>. Acesso em 21 out. 2018.

RANCIĖRE, J. O espectador emancipado. São Paulo: WMF Martins Fontes, 2012. 
RIBEIRO, L. Folha Uol, São Paulo, 26 de Fevereiro de 2012. Disponível em: <http:// www1.folha.uol.com.br/fsp/serafina/sr2602201204.htm>. Acesso em 21 out. 2018.

RIVERA, T. O avesso do imaginário: arte contemporânea e psicanálise. São Paulo: Cosac Naify, 2013.

SALKELD, R. Como ler uma fotografia. São Paulo: Gustavo Gili, 2014.

SHIKO. Talvez seja mentira. Independente, 2014.

TATE GALEIRA DE ARTE. Londres, Reino Unido. Exhibition \& Events. Disponível em: $<$ http://www.tate.org.uk/whats-on/tate-modern/exhibition/jeff-wall/jeff-wall-room-guide/jeff-wall-room-guide-room-3. Acesso em 21 out. 2018.

TILLMANS, W. Alemanha. Disponível em: <http://tillmans.co.uk/>. Acesso em 21 out. 2018.

VASQUES, P. A. Sonhos verdadeiros. a fotografia de Duane Michals: In: BONI, Paulo César. (org.). Fotografia: usos, repercussões e reflexões. Londrina: Midiograf, 2014. p. 210-257.

VINICIUS, M. Brasil, Maio 2014. Lounge. Disponível em: <http://lounge.obviousmag. org/cafe_nao_te_deixa_mais_cult/2014/04/por-de-tras-das-fotografias-de-sebastiao-salgado.html>. Acesso em 21 out. 2018.

ZAMBONI, Silvio. A pesquisa em arte: um paralelo entre arte e ciência. Campinas, SP: Autores Associados, 2006. 